\title{
The Asthma Awareness Patch Program for Girl Scouts: An Evaluation of Educational Effectiveness
}

\author{
Teresa A Volsko MHHS RRT FAARC, Marilyn Walton MHHS RRT RPSGT AE-C, \\ Kathryn A Tessmer PhD, Rachael J Pohle-Krauza PhD RD LD, and John T McBride MD
}

\begin{abstract}
BACKGROUND: Carefully designed educational programs can improve asthma knowledge, management practices, and health outcomes. We used pre-post testing to determine if the curriculum provided in the Girl Scouts of the USA Asthma Awareness Patch Program improved recipients' knowledge of basic respiratory system function, asthma pathophysiology, triggers, and asthma exacerbation recognition and management. We hypothesized that participants would have improved post-test scores following an interactive asthma educational program. METHODS: Girl Scouts ages 5-17 years from a 4-county area in northeastern Ohio were recruited. Educational components were in compliance with the guidelines established by the National Heart, Lung, and Blood Institute's National Asthma Education and Prevention Program. Participants completed a demographic form and pre-test before, and a post-test and program evaluation immediately following, the program. Descriptive statistics were used to report participant demographics. Frequencies and percentages described the participants' responses to pre- and post-test questions. Cronbach's alpha analysis determined internal consistency and reliability of post-test items. $T$ tests assessed differences in pre-post scores. Fishers exact tests determined differences in proportions of responses, between the pre- and post-test time points. A $P$ value of $<0.05$ was considered statistically significant. RESULTS: Eighty-six girls, between 5 and 16 years of age (mean \pm SD $8.97 \pm 2.36$ y) participated, $84 \%$ of whom were white. Twenty-one percent of the participants were diagnosed and treated for asthma, $48 \%$ resided with an asthmatic, and $72 \%$ knew someone with asthma. The post-test scores (mean \pm SD 89.6 \pm 9.0$)$ were significantly higher $(P<.001)$ than the pre-test scores $(62.5 \pm 20.8)$. A Cronbach alpha raw score of 0.448 and a standardized score of 0.518 were realized. CONCLUSIONS: The assessment tool demonstrated moderate internal reliability. Participation in the program enhanced participants' knowledge of lung function, trigger identification, asthma pathophysiology, and treatment. Key words: asthma; education; prevention. [Respir Care 2013;58(3): 458-464. (c) 2013 Daedalus Enterprises]
\end{abstract}

\section{Introduction}

Asthma is a rapidly growing problem with a major impact on children. Nationally, $13 \%$ of children under 18 years

\footnotetext{
Ms Volsko is affiliated with the Department of Respiratory Care, and Dr McBride is affiliated with the Department of Pediatrics, Akron Children's Hospital, Akron, Ohio. Ms Walton is affiliated with the Community Outreach, Education, and Support Center, Akron Children's Hospital Mahoning Valley, Youngstown, Ohio. Dr Tessmer is affiliated with the Department of Human Performance and Exercise Science, Youngstown State University, Youngstown, Ohio. Dr Pohle-Krauza is affiliated with the Department of Human Ecology, Youngstown State University, Youngstown, Ohio.
}

of age in the United States have had an asthma diagnosis and approximately $9 \%$ currently have asthma. ${ }^{1}$ The state

\footnotetext{
Ms Volsko presented a version of this paper at the OPEN FORUM of the AARC Congress 2011, held November 5-8, 2011, in Tampa, Florida.

The authors have disclosed no conflicts of interest.

Supplementary material related to this paper is available at http:// www.rcjournal.com.

Correspondence: Teresa A Volsko MHHS RRT FAARC, Department of Respiratory Care, Akron Children's Hospital, One Perkins Square, Akron OH 44308. E-mail: tvolsko@chmca.org.
}

DOI: $10.4187 /$ respcare. 01838 
of Ohio exceeds the national average and has a pediatric asthma prevalence of $12.3 \% .^{2}$ There is a quad county area in northeastern Ohio that exceeds the state's prevalence for asthma. Nearly 26,000 children, or approximately $14.9 \%$ of those under the age of 18 years, are affected with asthma in Mahoning, Trumbull, Columbiana, and Ashtabula counties. ${ }^{3}$ The city of Youngstown is the largest metropolitan city within this quad county area and is one of 7 Ohio metropolitan areas that are ranked in the top 100 most challenging places to live with asthma in the United States. ${ }^{4}$ Among the scoring factors, Youngstown ranked worse than average in prevalence and risk factors for asthma, including estimated asthma prevalence, crude death rate for asthma, and poverty rate (Table 1 ). There is a growing need for organized asthma disease management in this area. A collaborative between the Girl Scouts of North East Ohio, the Community Outreach, Education and Support Center at Akron Children's Hospital Mahoning Valley, and the faculty at The Bitonte College of Health and Human Services at Youngstown State University was formed to address asthma awareness and management principles to the residents of Mahoning Valley through an interactive program.

The Girl Scouts of North East Ohio is the local chapter of the Girl Scouts of the USA, serving girls in 18 counties. Girl Scouts participate in a variety of educational programs and activities that are designed to fulfill these objectives, and these activities are encouraged through use of a "patch" system. Patches are used to recognize a Girl Scout's achievement of competencies related to specific educational objectives. The fabric patches are affixed to each Scout's uniform, as a symbol of acquired knowledge. The Asthma Patch Program is available to Girl Scouts of all ages. This program addresses asthma awareness and disease management. The educational program this collaborative developed fulfilled the requirements needed to obtain an Asthma Awareness Patch, as set forth by the Girl Scouts of the USA, and was also in compliance with the guidelines established by the National Heart, Lung, and Blood Institute's National Asthma Education and Prevention Program. ${ }^{5}$

The purpose of this study was to determine if the curriculum provided in the Girl Scouts Asthma Awareness Patch Program improved knowledge of basic respiratory system function, asthma pathophysiology, asthma triggers, as well as recognition and management of an asthma exacerbation. We hypothesized that participants would have improved post-test scores immediately following an interactive asthma educational program.

\section{Methods}

Girls between the ages of 5-17 years who were active members of the Girl Scouts of the USA and Girl Scout

\section{QUICK LOOK}

\section{Current knowledge}

Appropriately designed asthma education programs can improve participant asthma knowledge, management, and outcomes. The Girl Scouts of the USA's asthma awareness and disease management program awards an Asthma Patch to participants.

\section{What this paper contributes to our knowledge}

The Asthma Patch program enhanced knowledge of normal lung function, asthma pathophysiology, trigger identification, and asthma treatment in a group of 517-year-old participants, and the participants rated the program favorably, potentially improving learning outcomes.

Leaders from a 4-county area in northeastern Ohio were eligible to participate. Flyers describing the program were distributed at scheduled troop leader meetings to recruit participants to the program. Troop leaders are adult volunteers designated by the Girl Scouts of the USA to supervise a Girl Scout troop. The flyers clearly delineated a program limit of 300 participants. The investigators did not directly recruit participants. Rather, the investigators attended troop leader meetings to discuss the study, distribute program flyers and registration forms, and answer any questions. The troop leaders then presented the program flyers to their respective troops and pre-registered Girl Scouts for the program if there was an interest. The institutional review boards at Akron Children's Hospital and Youngstown State University approved the study protocol. Parental consent was obtained prior to participation in this research endeavor. The consent form was integrated into the program registration form, which included consent for study participation and photograph release. Pre-registration was required to verify consent prior to program participation.

After obtaining informed consent, a standard demographic questionnaire was used to classify subjects' age and ethnicity, as well as record asthma diagnosis and/or familiarity with this disease process. A survey (pre-test) was used to test each participant's knowledge of asthma disease management. The pre- and post-tests contained 20 identical questions and were administered before and after the interactive educational sessions. The first 17 questions assessed knowledge of basic respiratory system function, asthma pathophysiology, asthma triggers, and management of an asthma exacerbation. Test scores were based on the number of correct responses to these 17 questions, with 100 designated as the maximum score. The last 3 questions asked the participants to rank their comfort level with 
Table 1. Comparison of the City of Youngstown With the Average Score for Factors Used to Compare and Rank the Metropolitan Areas Designated as the Most Challenging Places to Live With Asthma ${ }^{5}$

\begin{tabular}{|c|c|c|c|c|c|c|c|c|c|c|c|c|}
\hline & \multicolumn{3}{|c|}{ Prevalence Factors } & \multicolumn{6}{|c|}{ Risk Factors } & \multicolumn{3}{|c|}{ Medical Factors } \\
\hline & $\begin{array}{l}\text { Estimated } \\
\text { Asthma } \\
\text { Prevalence }\end{array}$ & $\begin{array}{l}\text { Self- } \\
\text { Reported } \\
\text { Asthma } \\
\text { Prevalence }\end{array}$ & $\begin{array}{l}\text { Crude } \\
\text { Death } \\
\text { Rate } \\
\text { for } \\
\text { Asthma }\end{array}$ & $\begin{array}{l}\text { Annual } \\
\text { Pollen } \\
\text { Score }\end{array}$ & $\begin{array}{c}\text { Air } \\
\text { Quality* }\end{array}$ & $\begin{array}{c}\text { "100\%" } \\
\text { Public } \\
\text { Smoke- } \\
\text { Free } \\
\text { Laws }\end{array}$ & $\begin{array}{l}\text { Poverty } \\
\text { Rate }\end{array}$ & $\begin{array}{l}\text { Uninsured } \\
\text { Rate }\end{array}$ & $\begin{array}{l}\text { School } \\
\text { Inhaler } \\
\text { Access } \\
\text { Law }\end{array}$ & $\begin{array}{c}\text { Use of } \\
\text { Quick Relief } \\
\text { Medications }\end{array}$ & $\begin{array}{c}\text { Use of } \\
\text { Controller } \\
\text { Medications }\end{array}$ & $\begin{array}{l}\text { Number of } \\
\text { Asthma } \\
\text { Specialists }\end{array}$ \\
\hline Average for each factor & $8.49 \%$ & $8.22 \%$ & $1.19 \%$ & $\begin{array}{c}45 \text { g per } \\
\text { cubic } \\
\text { meter } \\
\text { air } \\
\text { daily }\end{array}$ & $\begin{array}{l}\text { Average D } \\
\text { on A to } \\
\text { F scale }\end{array}$ & $\begin{array}{c}\text { Average } \\
2.16 \\
\text { on } 0 \\
\text { to } 4 \\
\text { scale }\end{array}$ & $14.39 \%$ & $17.24 \%$ & $\begin{array}{l}\text { All states } \\
\text { have } \\
\text { access } \\
\text { laws }\end{array}$ & $\begin{array}{l}2.17 \text { prescriptions } \\
\text { per estimated } \\
\text { patient }\end{array}$ & $\begin{array}{l}2.43 \text { prescriptions } \\
\text { per estimated } \\
\text { patient }\end{array}$ & $\begin{array}{l}3.36 \text { specialists } \\
\text { per } 10,000 \\
\text { estimated } \\
\text { patients }\end{array}$ \\
\hline $\begin{array}{l}\text { Ranking for Youngstown, } \\
\text { Ohio }\end{array}$ & $\phi$ & $\phi$ & $\mathrm{X}$ & $\phi$ & $\mathrm{X}$ & ○ & $\phi$ & ० & ○ & $\mathrm{X}$ & $\mathrm{X}$ & $\mathrm{X}$ \\
\hline $\begin{array}{l}\text { * Annual air quality is the po } \\
\phi=\text { worse than the average } \\
\mathrm{X}=\text { at the average } \\
\mathrm{O}=\text { better than the average }\end{array}$ & ollution levels & $\mathrm{s}$ and the nu & aber of ur & lthy o & or ozone & , score & on a sca & A to $\mathrm{F}$ & A bein & est and $\mathrm{F}$ the wor & & \\
\hline
\end{tabular}

providing assistance to someone during an exacerbation. The demographic questionnaire and asthma knowledge survey (pre-post test) are available as supplementary materials published online through RESPIRATORY CARE (see the supplementary materials at http://www.rcjournal.com).

\section{Educational Component}

Two 4 hour educational sessions were conducted. Participants were grouped by age, with girls ages $11-17$ in the morning session and those 5-10 in the afternoon. Each educational session grouped participants by age as follows:

Group 1: 15 and 17 years

Group 2: 11 and 14 years

Group 3: $9-10$ years

Group 4: 7-8 years

Group 5: 5-6 years

All participants followed the same program agenda and educational curriculum. Age appropriate activities were used with each educational module to complement the educational material presented and to reinforce learning. Each session contained 6 interactive educational modules, inclusive of an introduction to the program, how the lungs work with and without asthma, asthma triggers, medication use, exercise and a healthy lifestyle, and putting it all together: how to help yourself or someone who has asthma. Each module was 20 min in length. Program faculty were assisted by one or more of the study co-investigators, and respiratory care student volunteers, in order to allow each age group to be divided into smaller working groups of 6 to 8 participants. The smaller working groups provided an environment conducive to learning and to improved facilitation of group activities (Fig. 1). Faculty and volunteers received instruction on how to assist participants with the completion of assessment tools without cuing. The healthy living module was conducted by an Exercise Scientist and Registered Dietitian, and all asthma disease management components were conducted by Certified Asthma Educators. Participants were also asked to complete a program evaluation at the conclusion of the program, after completing the post-test. The evaluation tool ranked program elements on a Likert scale from 1 to 4 , with 4 being the highest ranking. A Flesch-Kincaid reading level was performed on the assessment tools and educational materials used in this program, and measured 5.3. The program agenda and curriculum are also available as supplementary materials published online through ReSPIRATORY CARE.

\section{Data Collection and Analysis}

Data were analyzed using statistics software (SPSS, 17.0, SPSS, Chicago, Illinois). Descriptive statistics were used to report participant demographics, program evaluation, and comfort level with providing assistance to someone during an exacerbation. Cronbach alpha analysis was used to determine internal consistency and reliability of posttest items. Dependent $t$ tests were used to assess differences in pre-post scores. In addition, frequencies and percentages were used to describe participants' responses to pre- and post-test questions, and Fisher exact tests were used to determine differences in proportions of these responses, between the pre- and post-test time points. A $P$ value of $<.05$ was considered statistically significant.

\section{Results}

Eighty-six girls between the ages of 5 and 16 years (mean \pm SD $8.97 \pm 2.36 \mathrm{y}$ ) participated. A majority of the participants were white (Table 2). Although nearly three quarters of participants reported having a familiarity with asthma (friend of family member), less than one quarter 


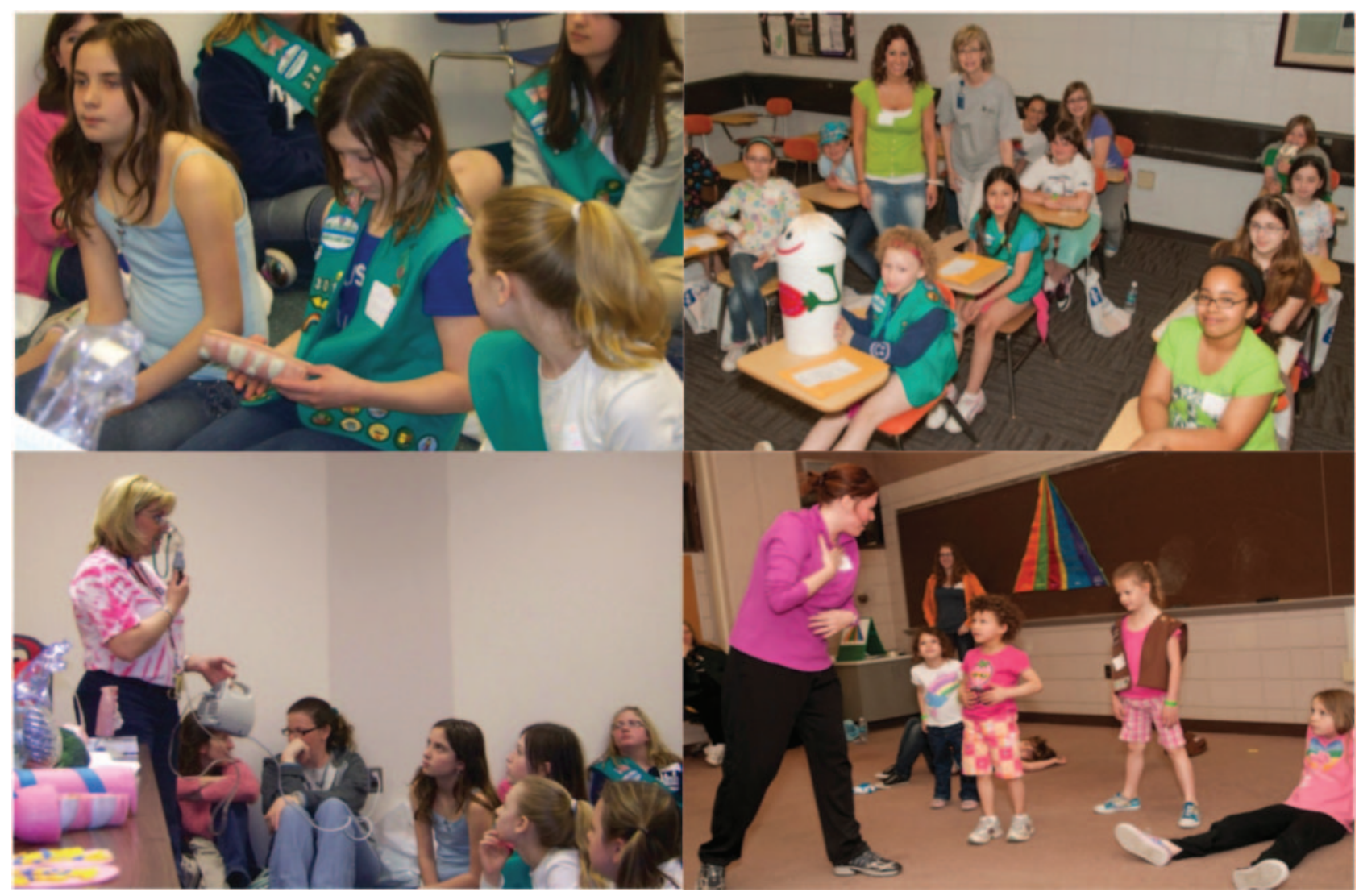

Fig. 1. Girl Scouts participating in the interactive educational sessions. Starting from the top left: how the lungs work in health and with asthma, trigger, medication administrations, and exercise and a healthy lifestyle.

Table 2. Ethnic Composition of Program Participants

\begin{tabular}{lcc}
\hline \hline \multicolumn{1}{c}{ Race } & $n$ & $\begin{array}{c}\text { \% Study } \\
\text { Population }\end{array}$ \\
\hline African American & 5 & 6 \\
Hispanic & 6 & 7 \\
White & 72 & 84 \\
Bi-racial & 3 & 3 \\
\hline
\end{tabular}

carried the diagnosis (Table 3). Sixty-seven percent of the children diagnosed with asthma were under the care of a primary care physician (PCP) or pulmonologist (see Table 3). Nearly one half of the children lived with someone who uses tobacco (see Table 3). All of the participants self-reporting a diagnosis of asthma also lived with someone with asthma. Pre-post assessment of asthma knowledge is found in Table 4. Participants reporting a diagnosis of asthma scored higher on the pre-test than those without an asthma diagnosis (Table 5). Although there was no difference in post-test scores between those with and without an asthma diagnosis, less variability in post-test scores was noted for all participants (see Table 5). Very few participants responded "I don't know" to the questions posed on the post test (Table 6). Moreover, there were significant differences in the distribution of pre-test versus post-test responses for the large majority of question items, reflecting larger numbers of participants responding correctly to question items at the post-test time point, compared to responses from the pre-test. After participating in the program a majority of participants reported increased sureness in feeling better trained and capable of providing assistance to someone during an exacerbation of asthma (Table 7). Internal consistency and reliability of post-test items yielded a Cronbach alpha raw score of 0.448 and a standardized score of 0.518 . A summary of the program evaluation is found in Table 8.

\section{Discussion}

This research endeavor was a community collaborative between Youngstown State University, Akron Children's Hospital Mahoning Valley, and the Girl Scouts of North East Ohio. The literature provides examples of utility of interdisciplinary collaboration with respect to asthma education, community awareness, and health promotion. Saini and colleagues investigated the effectiveness of a multi- 
Table 3. Participant Diagnosis, Familiarity With an Asthma Related Diagnosis and or Trigger Risk Factors

\begin{tabular}{|c|c|c|c|c|c|c|c|c|c|c|c|c|c|c|c|c|}
\hline & $\begin{array}{l}\text { Live With a } \\
\text { Family } \\
\text { Member } \\
\text { With Asthma }\end{array}$ & $\begin{array}{l}\text { Know } \\
\text { Someone } \\
\text { With } \\
\text { Asthma }\end{array}$ & $\begin{array}{c}\text { Have } \\
\text { Been } \\
\text { Told I } \\
\text { Have } \\
\text { Asthma }\end{array}$ & $\begin{array}{c}\text { Treated } \\
\text { by PCP } \\
\text { for } \\
\text { Asthma }\end{array}$ & $\begin{array}{c}\text { Treated } \\
\text { by a } \\
\text { Lung } \\
\text { Specialist }\end{array}$ & $\begin{array}{l}\text { Use an } \\
\text { Inhaler } \\
\text { or } \\
\text { Nebulizer } \\
\text { in School }\end{array}$ & $\begin{array}{c}\text { Use a } \\
\text { Peak Flow } \\
\text { Meter to } \\
\text { Monitor } \\
\text { Asthma }\end{array}$ & $\begin{array}{c}\text { Have an } \\
\text { Asthma } \\
\text { Action } \\
\text { Plan at } \\
\text { Home }\end{array}$ & $\begin{array}{c}\text { Have an } \\
\text { Asthma } \\
\text { Action } \\
\text { Plan at } \\
\text { School }\end{array}$ & $\begin{array}{l}\text { Take } \\
\text { Medicine } \\
\text { for } \\
\text { Asthma } \\
\text { Daily }\end{array}$ & $\begin{array}{c}\text { Take } \\
\text { Medicine } \\
\text { PRN for } \\
\text { Breathing } \\
\text { Difficulty }\end{array}$ & $\begin{array}{l}\text { Live With } \\
\text { Someone } \\
\text { That } \\
\text { Smokes }\end{array}$ & $\begin{array}{c}\text { Type of T } \\
\text { Cigarettes }\end{array}$ & Cigars & Pipe & osure \\
\hline$n$ & 41 & 62 & 18 & 12 & 7 & 10 & 1 & 9 & 10 & 3 & 16 & 39 & 37 & 4 & 0 & 2 \\
\hline$\%$ study population & 48 & 72 & 21 & 14 & 8 & 12 & 1 & 10 & 12 & 3 & 19 & 45 & 43 & 5 & 0 & 2 \\
\hline \multicolumn{17}{|c|}{$\begin{array}{l}\mathrm{PCP}=\text { primary care physician } \\
\mathrm{PRN}=\text { }\end{array}$} \\
\hline
\end{tabular}

Table 4. Pre- and Post-Program Evaluation of Asthma Knowledge

\begin{tabular}{cccc}
\hline \hline & Pre Score & Post Score & $P$ \\
\hline Mean \pm SD & $62.5 \pm 20.8$ & $89.6 \pm 9.0$ & $<.001$ \\
\hline
\end{tabular}

disciplinary approach to asthma awareness and education with school-age children. They demonstrated improved asthma knowledge among the participants and increased public awareness of the importance of having different healthcare disciplines participate in asthma education and care. ${ }^{6}$ The Chicago Asthma Consortium and the American Lung Association of Metropolitan Chicago instituted a very broad-based community collaborative that successfully influenced public policy, which permitted students to carry inhalers in schools, improved private insurance coverage for inhalers, advanced tobacco control and clean air policy within the city, reduced youth access to tobacco, and developed targeted tax funding for asthma and lung disease research. ${ }^{7}$

The Asthma Awareness Patch Project had a narrower scope than the aforementioned collaboratives. Since the Girl Scouts of the USA had an established patch program, the core curriculum was used by the interdisciplinary team of educators for this endeavor. The Asthma Patch Program was originally developed by the Girls Scouts of the USA, American Lung Association, American Academy of Allergy, Asthma, and Immunology, and the Asthma Coalition of Long Island, and has been available to Girl Scouts of all ages since 2005. Historically, this patch was never awarded to Girl Scouts in northeastern Ohio.

Although the authors were knowledgeable of aggregate data for asthma prevalence in the target population, the authors did not have prior knowledge of the medical background of study participants. There was speculation that some of the participants may have asthma, merely due to the prevalence of this chronic lung disease in this quad county area of northeastern Ohio. Although a minority of participants were diagnosed with asthma $(21 \%)$, all received care by either a PCP or pulmonologist. Only one child reported receiving care by both a specialist and a PCP. Access to care within this small segment of the pop-
Table 5. Comparison of Pre- and Post-Program Assessment Scores, Among Participants With and Without an Asthma Diagnosis

\begin{tabular}{lcc}
\hline \hline & $\begin{array}{c}\text { Pre-Score } \\
\text { Mean } \pm \text { SD }\end{array}$ & $\begin{array}{c}\text { Post-Score } \\
\text { Mean } \pm \text { SD }\end{array}$ \\
\hline Participant self-report of asthma diagnosis & $75.6 \pm 14.5$ & $90.1 \pm 7.3$ \\
No diagnosis of asthma & $59.3 \pm 20.9$ & $89.5 \pm 9.5$ \\
$P$ & .001 & .76 \\
\hline
\end{tabular}

ulation did not appear to be problematic. However, the number of participants with asthma was so small that this finding could not be generalized to the population at large within the Mahoning Valley. Poor access to healthcare, lack of educational resources, and absence of an asthma management plan contribute to increased morbidity and mortality. ${ }^{8-11}$ Although families may have good intentions for eliminating the triggers, as well as seeking and/or following the prescribed plan of care, many are faced with the dilemma of prioritizing basic survival needs. As a result, the medical needs of their child or children may carry a lower priority out of sheer necessity, rather than desire. It is worthwhile for community partnerships to be formed to address the barriers to attaining and maintaining the health of our youth. To demonstrate the value of community based health services for patients with asthma or of asthma self-management programs, it is of value to report healthcare resource utilization (ie, emergency room visits, hospital readmissions) as a program outcome measure. ${ }^{12-15}$

Although the length of this asthma awareness program was relatively short, its effect on asthma knowledge was profound. Program participants realized statistically significant improved post-test scores $(P<.001)$. Less variability in pre-post-score scores was also noted. The standard deviations of the mean scores were 20.8 for the pretest and 9.0 for the post-test. Those reporting an asthma diagnosis scored on average 16.3 points higher on the pre-test than those without an asthma diagnosis ( 75.6 vs 59.3). This subset of individuals all reported receiving asthma care by either a PCP or pulmonologist. Information regarding asthma education prior to participation in the Asthma Patch Program was not ascertained. There is a 
Table 6. Participants' Responses Before and After the Asthma Awareness Patch Program

\begin{tabular}{|c|c|c|c|c|c|c|c|}
\hline \multirow{2}{*}{ Question } & \multicolumn{3}{|c|}{$\begin{array}{l}\text { Pre-test Response Distribution, } \\
\text { no. (\%) }\end{array}$} & \multicolumn{3}{|c|}{$\begin{array}{c}\text { Post-Response Distribution, } \\
\text { no. }(\%)\end{array}$} & \multirow{2}{*}{$P^{*}$} \\
\hline & Yes & No & I don't know & Yes & No & I don't know & \\
\hline We breathe in oxygen. & $77(90)$ & $3(3)$ & $6(7)$ & $83(97)$ & $3(3)$ & $0(0)$ & .002 \\
\hline We breathe out carbon dioxide. & $48(55)$ & $15(17)$ & $23(27)$ & $74(86)$ & $9(11)$ & $3(3)$ & $<.001$ \\
\hline The diaphragm is the main muscle of breathing. & $35(40)$ & $9(10)$ & $42(49)$ & $73(85)$ & $10(12)$ & $3(3)$ & .01 \\
\hline Asthma can make it hard to breathe. & $77(88)$ & $2(2)$ & $7(8)$ & $86(100)$ & $0(0)$ & $0(0)$ & $\dagger$ \\
\hline $\begin{array}{l}\text { In asthma the airways become smaller, swollen, } \\
\text { and filled with mucus. }\end{array}$ & $53(60)$ & $5(6)$ & $28(33)$ & $83(97)$ & $81(94)$ & $0(0)$ & .07 \\
\hline $\begin{array}{l}\text { Coughing, wheezing, chest pain, and trouble } \\
\text { breathing can happen with an asthma flare-up. }\end{array}$ & $65(74)$ & $4(5)$ & $17(20)$ & $86(100)$ & $0(0)$ & $0(0)$ & $\dagger$ \\
\hline I can catch asthma from a friend. & $8(9)$ & $66(77)$ & $11(13)$ & $5(6)$ & $81(94)$ & $0(0)$ & .04 \\
\hline $\begin{array}{l}\text { Cough, headache, and stomach ache can be } \\
\text { "early warning signs" of an asthma flare-up. }\end{array}$ & $34(39)$ & $19(22)$ & $33(38)$ & $77(90)$ & $9(10)$ & $0(0)$ & .012 \\
\hline $\begin{array}{l}\text { All asthma medicines work the same way to } \\
\text { help breathing get better. }\end{array}$ & $29(33)$ & $36(42)$ & $21(24)$ & $27(31)$ & $58(67)$ & $0(0)$ & $<.001$ \\
\hline $\begin{array}{l}\text { It is good to use a "spacer" with an inhaler or } \\
\text { Puffer. }\end{array}$ & $35(40)$ & $10(12)$ & $41(48)$ & 85 (99) & $0(0)$ & $1(1)$ & .48 \\
\hline $\begin{array}{l}\text { It is good to take albuterol at the first sign of a } \\
\text { cold or asthma flare-up. }\end{array}$ & $29(33)$ & $12(14)$ & $45(52)$ & $66(77)$ & $10(12)$ & $10(12)$ & .006 \\
\hline $\begin{array}{l}\text { It is important to stay calm when someone is } \\
\text { having trouble breathing. }\end{array}$ & $65(74)$ & $12(15)$ & $8(9)$ & $79(92)$ & $7(8)$ & $0(0)$ & $<.001$ \\
\hline $\begin{array}{l}\text { You should call a doctor if breathing does not } \\
\text { get better after taking asthma medicine. }\end{array}$ & $75(85)$ & $2(2)$ & $9(10)$ & $82(95)$ & $2(2)$ & $2(2)$ & $<.001$ \\
\hline $\begin{array}{l}\text { Smoking is a healthy choice for people with } \\
\text { asthma. }\end{array}$ & $64(73)$ & $18(21)$ & $4(5)$ & $69(80)$ & $17(20)$ & $0(0)$ & $<.001$ \\
\hline Smoking is a healthy choice for any person. & $64(73)$ & $18(21)$ & $4(5)$ & $71(83)$ & $15(17)$ & $0(0)$ & $<.001$ \\
\hline $\begin{array}{l}\text { Exercise, weather, and strong smells can trigger } \\
\text { an asthma flare-up. }\end{array}$ & $48(55)$ & $12(14)$ & $26(30)$ & $78(91)$ & $6(7)$ & $2(2)$ & .02 \\
\hline I know what a written asthma action plan is. & $12(14)$ & $30(35)$ & $44(51)$ & $68(79)$ & $10(12)$ & $8(9)$ & .002 \\
\hline
\end{tabular}

Table 7. Participants' Familiarity With and Attitudes Toward Their Ability to Help Someone During an Exacerbation of Asthma Before and After the Asthma Awareness Patch Program

\begin{tabular}{|c|c|c|c|c|c|c|c|c|c|c|}
\hline & \multicolumn{10}{|c|}{ Percent of Respondents } \\
\hline & \multicolumn{2}{|c|}{$\begin{array}{l}\text { Not Sure } \\
\text { at All }\end{array}$} & \multicolumn{2}{|c|}{$\begin{array}{c}\text { Not } \\
\text { Very Sure }\end{array}$} & \multicolumn{2}{|c|}{$\begin{array}{l}\text { Somewhat } \\
\text { Sure }\end{array}$} & \multicolumn{2}{|c|}{ Pretty Sure } & \multicolumn{2}{|c|}{ Very Sure } \\
\hline & Pre & Post & Pre & Post & Pre & Post & Pre & Post & Pre & Post \\
\hline $\begin{array}{l}\text { I am sure I know how to help a friend who } \\
\text { is having trouble breathing. }\end{array}$ & 24 & 0 & 15 & 1 & 20 & 9 & 23 & 33 & 17 & 57 \\
\hline $\begin{array}{l}\text { I am sure I have the training to help a } \\
\text { friend with asthma. }\end{array}$ & 44 & 0 & 13 & 7 & 16 & 12 & 14 & 36 & 13 & 45 \\
\hline $\begin{array}{l}\text { I am sure I would know who to ask for } \\
\text { help if I saw a friend having trouble } \\
\text { breathing. }\end{array}$ & 9 & 0 & 10 & 1 & 7 & 0 & 27 & 17 & 47 & 81 \\
\hline
\end{tabular}

dearth of information available supporting the effectiveness of asthma education by the PCP. Although there are teachable moments during office visits, physicians may not consistently capitalize on all of the essential elements of asthma education during those opportunities. In a cross- sectional survey of 150 children with asthma seeking treatment, Orrell-Valente et al reported that the licensed healthcare provider did not consistently provide comprehensive asthma education and that education was less frequently provided to younger children (age $8-10$ y). ${ }^{16}$ 


\section{The Asthma Awareness Patch Program for Girl Scouts}

Table 8. Participant Evaluation of the Program Reported on a Scale Of 1-4, With 4 Being Most Favorable

\begin{tabular}{ccccc}
\hline \hline & & \% Respondents & \\
\cline { 2 - 6 } & $\begin{array}{c}\text { Program Helped } \\
\text { Me Learn } \\
\text { About Asthma }\end{array}$ & $\begin{array}{c}\text { Teachers } \\
\text { Explained } \\
\text { Things Well }\end{array}$ & $\begin{array}{c}\text { Activities } \\
\text { Were Fun }\end{array}$ & $\begin{array}{c}\text { Length of Program } \\
\text { Was Good }\end{array}$ \\
\hline 4 & 77 & 77 & 64 & 53 \\
Information \\
to Take Home
\end{tabular}

The Asthma Patch Program was well received. The Girl Scouts rated the program favorably, which may have had a positive effect on learning outcomes.

There were limitations to this study. The sample size was relatively small. The research intended to recruit 300 participants (150 in each session). This small sample may have contributed to the mediocre Cronbach alpha we realized. It also made it difficult to conduct subanalyses between age groups or between asthmatics and non-asthmatics within age groups. Additionally, the ethnic composition of the sample was not as diverse as the population of interest. A concerted effort to recruit a more diverse group of girls to the Girl Scouts organization prior to the commencement of the program may have provided a more diverse sample.

\section{Conclusions}

The Asthma Awareness Patch Program facilitated community engagement with an at-risk population. Participation in the program enhanced participants' knowledge of lung function, asthma pathophysiology, trigger identification, and asthma treatment.

\section{REFERENCES}

1. U.S Department of Health and Human Services. Centers for Disease Control and Prevention. National Center for Health Statistics. Summary health statistics for US adults: national health interview survey 2007. Vital Health Stat 2009;10(240). http://www.cdc.gov/nchs/data/ series/sr_10/sr10_240.pdf. Accessed January 4, 2013.

2. National Survey of Children's Health. http://www.nschdata.org/Data Query/DataQueryResults.aspx. Accessed January 4, 2013.

3. Ohio Department of Health. Asthma local profiles. http://www.odh. ohio.gov/odhPrograms/eh/asthma/asthdata/locpro.aspx. Accessed January 4, 2013.

4. Asthma and Allergy Foundation of America. 2009 Asthma capitals: the most challenging places to live with asthma. http://www.aafa.org/ pdfs/2009ACPublicList.PDF. Accessed January 4, 2013.

5. US Department of Health and Human Services. National Institute of Health, National Heart, Lung, and Blood Institute. National
Asthma Education and Prevention Program. Expert Panel Report 3: guidelines for the diagnosis and management of asthma. http://www. nhlbi.nih.gov/guidelines/asthma/asthgdln.pdf. Accessed January 4, 2013.

6. Saini B, Shah S, Kearey P, Bosnic-Anticevich S, Grootjans J, Armour C. An interprofessional learning module on asthma health promotion. Am J Pharm Educ 2011;75(2):1-10.

7. Shannon JJ, Catrambone CD, Coover L. Targeting improvements in asthma morbidity in Chicago: a 10 year retrospective of community action. Chest 2007;132(5):866S-873S

8. Guilbert TW, Garris C, Jhingran P, Bonafede M, Tomaszewski KJ, Bonus T, et al. Asthma that is not well-controlled is associated with increased healthcare utilization and decreased quality of life. J Asthma 2011;48(2):126-132.

9. Flores G, Snowden-Bridon C, Torres S, Perez R, Walter T, Brotanek J, Lin H, Tomany-Korman S. Urban minority children with asthma: substantial morbidity, compromised quality and access to specialists, and the importance of poverty and specialty care. J Asthma 2009; 46(4):392-398.

10. Murphy KR, Meltzer EO, Blaiss MS, Nathan RA, Stoloff SW, Doherty DE. Asthma management and control in the United States: results of the 2009 Asthma Insight and Management survey. Allergy Asthma Proc 2012;33(1):54-64.

11. Fuhrman C. Hospitalizations for asthma in children are linked to undertreatment and insufficient asthma education. J Asthma 2011; 48(6):565-571.

12. Fox P, Porter PG, Lob SH, Boer JH, Rocha DA, Adelson JW. Improving asthma-related health outcomes among low-income, multiethnic, school-aged children: results of a demonstration project that combined continuous quality improvement and community health worker strategies. Pediatrics 2007;120(4):902-911.

13. Beckham S, Kaahaaina D, Voloch KA, Washburn A. A communitybased asthma management program: effects on resource utilization and quality of life. Hawaii Med J 2004;63(4):121-126.

14. Diedhiou A, Probst JC, Hardin JW, Martin AB, Xirasagar S. Relationship between presence of a reported medical home and emergency department use among children with asthma. Med Care Res Rev 2010;67(4):450-475.

15. Ahmad E, Grimes DE. The effects of self-management education for school-age children on asthma morbidity: a systematic review. J Sch Nurs 2011;27(4):282-292.

16. Orrell-Valente JK, Jones K, Manasse S, Thyne SM, Shenkin BN, Cabana MD. Children's and parents' report of asthma education received from physicians. J Asthma 2011;48(8):831-838. 